\title{
Correction to: The Three-Case Argument against the Moral Justificatory Significance of Basic Desert
}

\author{
Aleksandr Mishura ${ }^{1}$ \\ Published online: 20 January 2022 \\ (c) Springer Nature B.V. 2022

\section{Correction to: Philosophia https://doi.org/10.1007/s11406-021-00442-3}

The original version of the article unfortunately contained mistakes. The Acknowledgements as shown below should be added in this paper.

Acknowledgements I would like to thank Sergei Levin, Elia Zardini and the reviewers of Philosophia for their extensive and very helpful comments. The text was prepared with the support of the Higher School of Economics, project "Naturalisation of Ethics: Natural Science Approaches to Free Will and Moral Responsibility".

The original article has been corrected.

Publisher's Note Springer Nature remains neutral with regard to jurisdictional claims in published maps and institutional affiliations.

The original article can be found online at https://doi.org/10.1007/s11406-021-00442-3

Aleksandr Mishura amishura@hse.ru

1 HSE University, Moscow, Russia 